J. Product. \& Dev., 24(1): 1 - 14(2019)

\title{
MORPH PHYSIOLOGICAL TRAITS OF SAFFLOWER AS AFFECTED BY PLANT DENSITIES AND NITROGEN FERTILIZATION
}

\section{ABSTRACT:}

This study carried out at a private farm in Elmhamid village ,Arment district , Luxor governorate, Egypt in 2016/2017 and 2017/2018 growing seasons for determine the effect of plant densities, different nitrogen sources and doses on the safflower $c v$. Giza (carthamus tinctorius) morphological and physiological characteristics.

The experimental design was split-split plot set up with three replicates in both studied seasons was followed. The main plots were devoted to three plant densities viz, 35, 47 and 70 thousand plants/fad., and sub-plots were allotted to the three forms of nitrogen, i.e. ammonium sulphate, ammonium nitrate and urea, while the four nitrogen fertilizer levels were randomely arranged in the sub-subplots. The highest plant density of 70000 plants fad. $^{-1}$ recorded the highest values of plant height and LAI at the growth stages i.e 65, 86 and 107 days from sowing in both seasons, while, the lowest plant density of 35000 plants/fad. ${ }^{-1}$ recorded highest values of number of green leaves plants/fad. ${ }^{-1}$, number of branches plants ${ }^{-1}$, dry weight plants $^{-1}(\mathrm{gm})$ and leaf area plants ${ }^{-1}$ in the three growth stages in both growing seasons.

The nitrogenous fertilizer forms had a significant effects on plant height at 107 days in the two growing seasons, But the other studied traits not show any significant response by the studied treatments under the two growing season at any growth stages. The highest values were recorded by using urea as the best form of nitrogen fertilizer under this experiment conditions.

The nitrogenous fertilizer levels had a significant effects on all studied traits at the different growth stages and the two growing seasons indicated the important of nitrogen fertilization on safflower under site of experiment. 
Conclusively, from these results it could be concluded that to increase the number of branches' / plant and leaf area index should be apply $60 \mathrm{~kg} / \mathrm{fed}$ level of nitrogen with low plant density.

Key words: Safflower, plant density, nitrogen forms, nitrogen doses, morphological-physiological traits.

\section{INTRODUCTION}

Safflower became a major oil seed in many countries in the world like U.S.A, especially after $2^{\text {nd }}$ world war, when breeders produced high yielding, high oleic oil cultivars with greater resistance to biotic and abiotic stresses, But it suffered severally from competition main winter crops in Egypt, i.e. berssem and wheat. Still the local edible oil production, in Egypt, is not sufficient. Safflower may play an important role in increasing edible oil production in new reclaimed soils in Egypt (Abu-Hagaza et. al., 2009).

In Egypt, Weiss (2000) mentioned that determination of the optimum plant population for a particular area under specific cropping condition is essential to optimize yield. Plant densities are needed to be accurately established. The present stand (number of plants) of safflower may be insufficient to produce high yield via land races and the exotics, since a considerable number of plants may be lost during the growing season. Therefore, higher plant densities could be more suitable to compensate for this loss and insure higher yield.

Many researchers reported that plant densities had a significant effect on safflower yield and its components. Yau (2009) found that plant height decreased by increasing plant density. Sharifmghaddasi and Omidi (2009) and Amoughin et al.(2012) illustrated that increasing plant density increased plant height. By contrast, number of branches $\mathrm{m}^{-2}$ decreased. Number of capitula plant or $\mathrm{m}^{-2}$ decreased by increasing the plant density (Elfadl et al., 2009 Sharifmghaddasi and Omidi (2009), Emami et al., 2011, Amoughin et al. (2012) . In addition, Shahri et al, (2013) reported that increasing plant density increased number of capitula per unit area but decreased 1000-seed weight. Conversely, Sharifmghaddasi and Omidi (2009) and Emami et al., (2011) mentioned that 1000 -seed weight was increased by increasing plant density.

The reactions of different forms and doses of nitrogen fertilizers are varied mach. Ahmed et al. (1985) studied that various doses of nitrogen had a significant positive effects on the plant height, number of branches, flowering percentage, the seed yield, 1000 seed number and protein content in seeds. 
Cabi (1990) detected a significant differences in the number of branches, number of head of safflower grown under different nitrogen fertilizer forms and doses in Samsun, Turkey and recommended the ammonium nitrate in 150 $\mathrm{kg} \mathrm{N} / \mathrm{ha}$ doses in order to get optimum seed yield in that region. Tamer et al. (2015) reported that increasing $\mathrm{N}$ rate with wider row distance influenced plant height, number of branch per plant, number of head per plant, 1000 seed weight, seed yield and seed protein content positively.

Therefore, the aimed of this study the effect of plant densities and nitrogen fertilization on morph physiological traits of safflower.

\section{MATERIALS AND METHODS}

Two field experiments were carried out at a Private farm, El-Mahamid Village, Arment District, Luxor, Egypt, during the two winter seasons of 2016/2017 and 2017/2018. This investigation aim to study the effect of plant density, nitrogen Fertilizer rates and sources on growth, Giza (1) safflower cultivar.

\section{Plant densities:}

Three plant densities were used:
(a) 35.000 plants fad $^{-1}$ i.e. $40 \mathrm{~cm}$ distance between plants.
(b) 47.000 plants $\mathrm{fad}^{-1}$ i.e. $30 \mathrm{~cm}$ distance between plants.
(c) 70.000 plants fad ${ }^{-1}$ i.e. $20 \mathrm{~cm}$ distance between plants.

\section{Nitrogen sources:}

Three nitrogen fertilizers forms were used:
(a) Urea $(46 \% \mathrm{~N})$
(b) Ammonium sulphate $(20.6 \% \mathrm{~N})$
(c) Ammonium nitrate $(33.5 \% \mathrm{~N})$

3. Nitrogen fertilization rates:

Four nitrogen rates were used:
(a) Zero (Control).
(b) $30 \mathrm{~kg} \mathrm{~N}$ fad $^{-1}$.
(c) $45 \mathrm{~kg} \mathrm{~N}$ fad $^{-1}$.
(d) $60 \mathrm{~kg} \mathrm{~N} \mathrm{fad}^{-1}$.

Experimental design: 
The Split-Split-plot design with three replicates in both 2016/2017 and 2017/2018 seasons was followed. The main plots were devoted to three plant densities, viz, 35, 47 and 70 thousand plants fad ${ }^{-1}$. The sub-plots were allotted to the three sources of nitrogen, i.e. ammonium sulphate, ammonium nitrate and urea. The four nitrogen fertilizer rates were random arranged in the subsub- plots. Each sub-sub-plot included 5 ridges $3 \mathrm{~m}$ long and $60 \mathrm{~cm}$ wide. The outer two ridges $\left(1^{\text {st }}\right.$ and $\left.5^{\text {th }}\right)$ were considered as a border ridges. Two ridges from the remaining three were used for sampling to study the growth and growth analysis.

\section{Cultural practices:}

The preceding crop was Lupin in the two seasons. Date of sowing was $7 / 11 / 2016$ and 13/11/2017. The crop was thinned to two plants per hill before the second irrigation practiced after30 days from sowing. The amount of nitrogen dose was applied twice after thinning and before the third irrigation. The normal cultural practices for safflower crop were Kept. The mechanical and chemical analysis the experimental soil are presented in Table (1).

Table (1): Mechanical and chemical analysis of the experimental fields of 2016/ 2017and 2017/2018 season.

\begin{tabular}{|c|c|c|}
\hline Soil content & 2016/2017 season & 2017/2018 season \\
\hline \multicolumn{3}{|l|}{ Mechanical analysis: } \\
\hline Coarse sand \% & 45.10 & 45.90 \\
\hline Fine sand \% & 35.90 & 36.10 \\
\hline Silt\% & 7.90 & 7.85 \\
\hline Clay \% & 11.10 & 10.15 \\
\hline Soil texture & Sandy & Sandy \\
\hline \multicolumn{3}{|l|}{ Available soil nutrients: } \\
\hline $\mathrm{NP}_{2} \mathrm{O}_{5} \mathrm{ppm}$ & 5.70 & 7.15 \\
\hline $\mathrm{P}_{2} \mathrm{O}_{5} \mathrm{ppm}$ & 4.11 & 3.90 \\
\hline $\mathrm{K}_{2} \mathrm{O} \mathrm{ppm}$ & 80.10 & 72.42 \\
\hline $\mathrm{pH}$ & 7.8 & 7.6 \\
\hline
\end{tabular}

Growth and growth analyses were determined on sample of five guarded plants. Sampling began after 65 days from sowing and continued up to 107 days at three weeks intervals in both 2016/2017 and 2017/2018 seasons. Samples were carried immediately to the laboratory and were separated into leaves, branches, stems and flowers. Fresh weigh was determined and a 50 gms from each was dried to constant weight, i.e. for about 48 hours at $75^{\circ} \mathrm{C}$. 
Morphological and physiological growth traits :

1.Plant height(cm) was measured from the ground surface to the terminal head at successive stages of plant growth.

2. Number of green leaves plant ${ }^{-1}$ : were accounted at successive stages of plant growth.

3. Number of branches plant ${ }^{-1}$ : were counted at all stages of growth, except the first stage.

4.Dry weight plant ${ }^{-1}$ : Dry matter content of the plant was calculated by the following equation:

$$
\text { Dry matter }=\quad \frac{\text { dry weight of the sample. }}{\text { fresh weight of the Sample }}
$$

5. Leaf area (LA): the disc method was used according to the method described by Johnson (1967). The cross sectional areas of the punch used was $1.77 \mathrm{~cm}^{2}$ and 50 discs were taken for all samples. Leaf area per plant was calculated as square dice meters $\left(\mathrm{dm}^{2}\right.$ plant $\left.{ }^{-1}\right)$.

6. Leaf area index (LAI) : Leaf area index resulted by dividing leaf area per plant over area occupied by a plant i.e. ( leaf area per unit area of ground )

$$
\text { LAI }=\frac{\text { Leaf area plant }^{-1}}{\text { Unit area of ground }}
$$

\section{Statistical analysis:}

The proper statistical analysis of split-plot design was used- Combined analysis was performed for the characters recorded in both seasons. Differences among treatments were judged according to Duncan's Multiple Range Test (Duncan, 1955). Means followed by different letters were statistically significant. In interaction Tables, Small letters were used to compare the means in columns, whereas capital ones were used to compare means in rows.

\section{RESULTS AND DISCUSSION}

\section{1- Effect of plant density:}

Data in Tables (2, 3 and 4) revealed that plant height, number of branches plant, dry weight/plant, leaf area and leaf area index were significantly affected by different plant densities. 


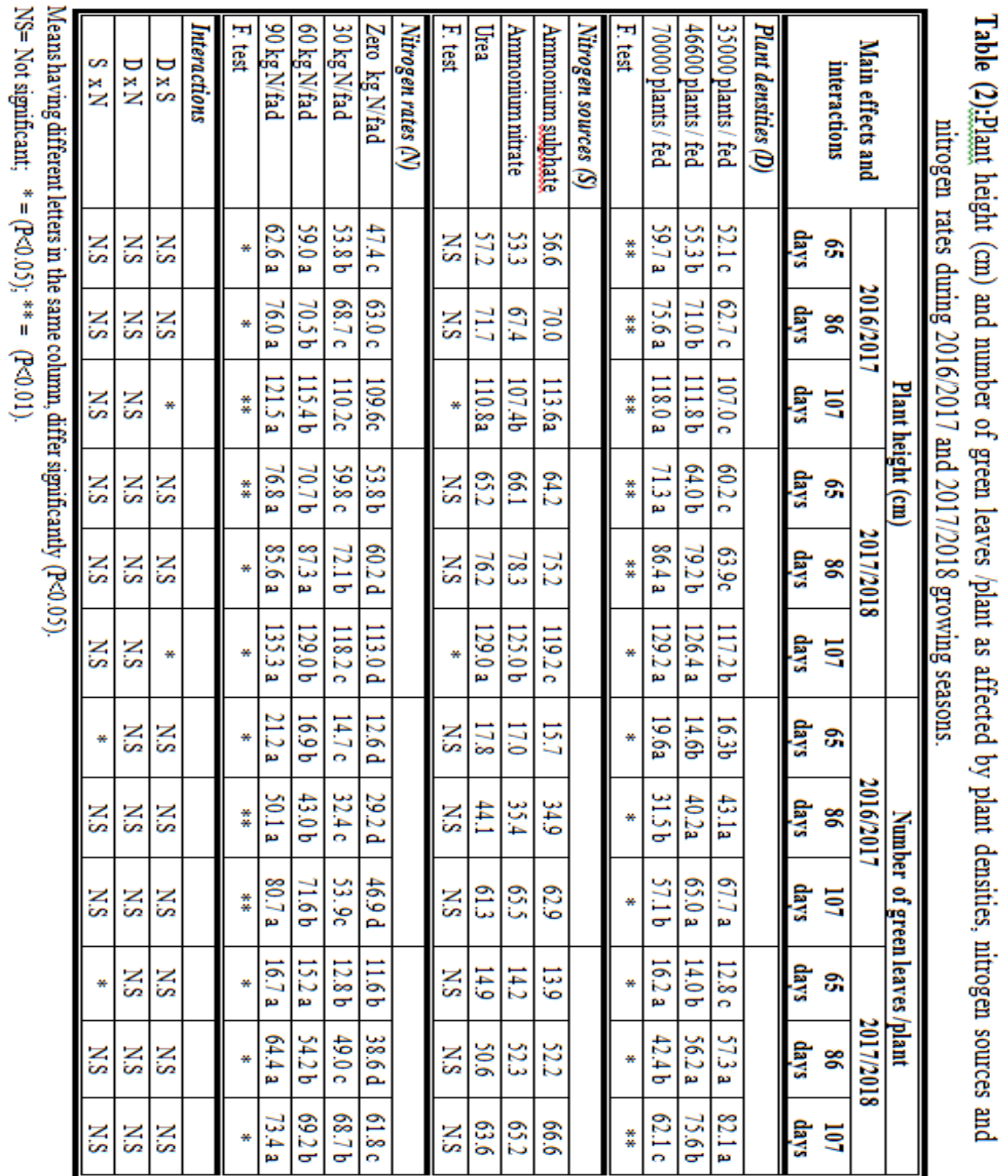




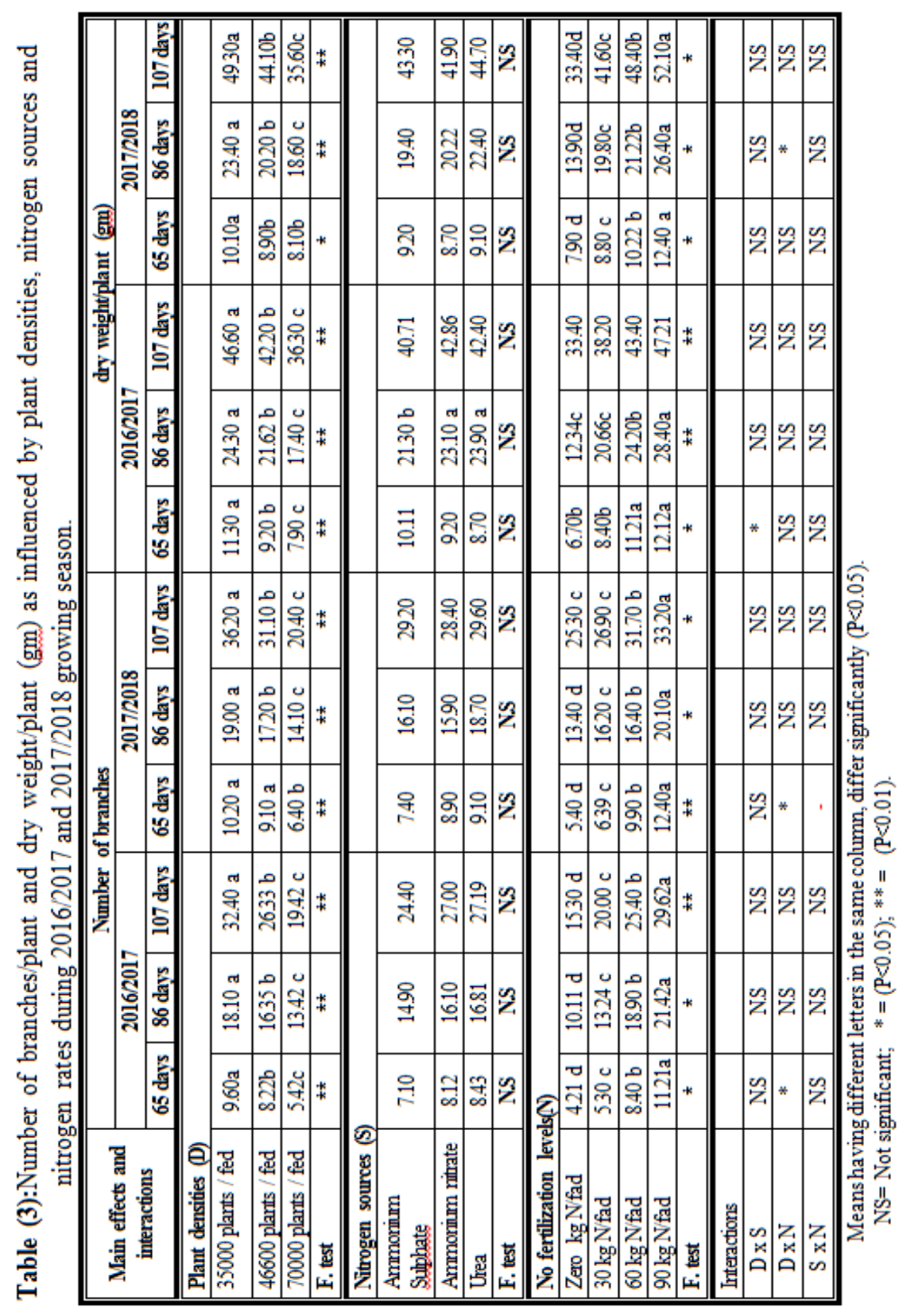




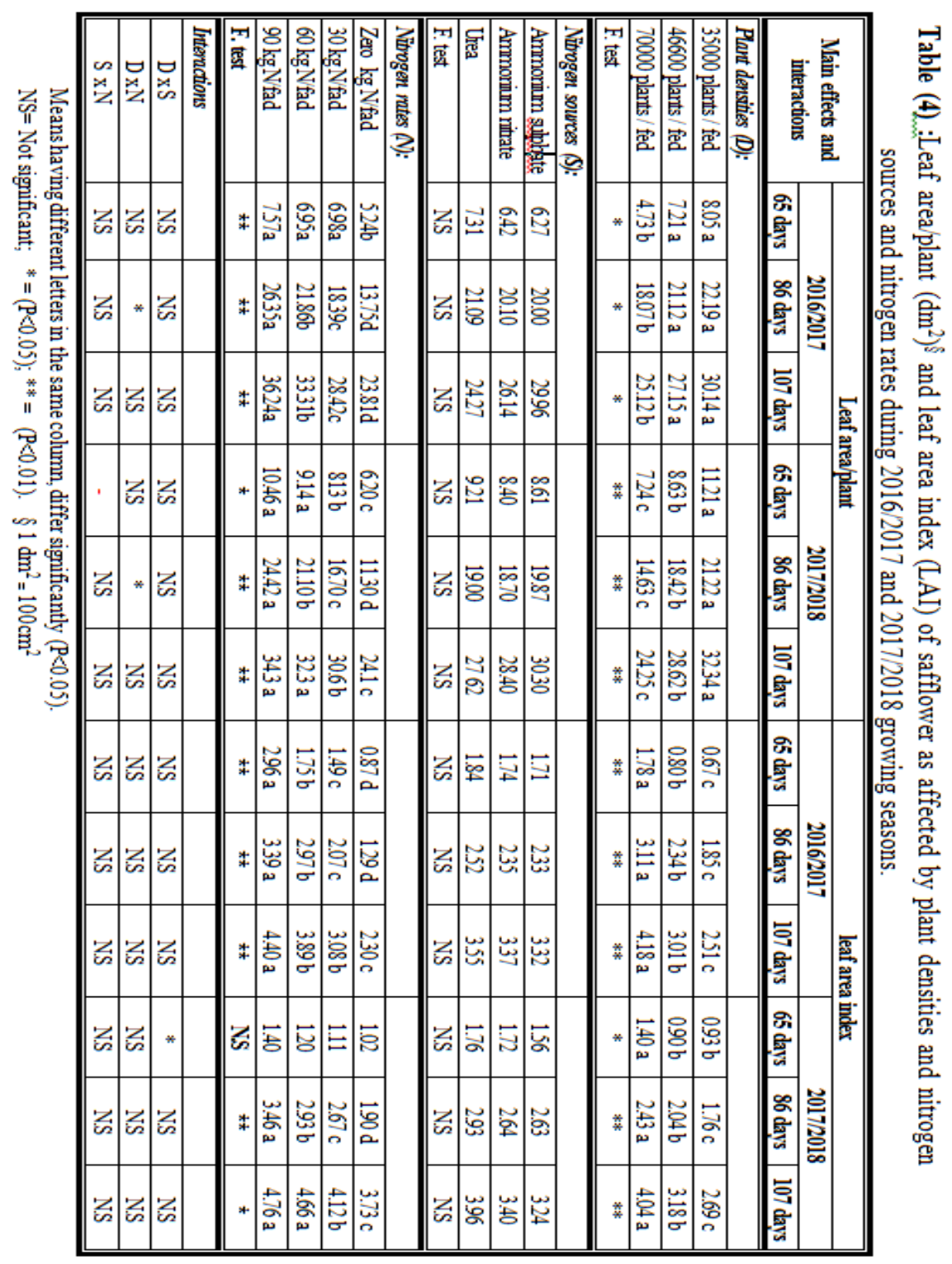


The present results showed that plant density gradually decreased plant growth up to 70000 plant/fed., due to reducing the light absorption inside the plant canopy and creating competition among plants. Similar trends, were obtained by sharifmhaddasi and Omidi (2009), Yau (2009), Amoughin et al. (2012a) and Hamza (2015). They concluded that with in increasing plant density decreased the plant growth.

Concerning number of green leaves/plant in both studied seasons, the obtained results in these mentioned tables showed that this trait significantly affected by plant density. Where the number of green leaves/ plant decreased by increasing plant density up to 70000 plant/fed. These results are harmony with those obtained results by Hamza (2015).

As well as, number of branches/plant and dry weight significantly affected by plant density and the results in Tables 2 , clearly indicate that number of branches/plant and dry weight/plant were decreased by increasing plant density up to 70000 plant/fed. in both seasons and these results are similar by the results obtained by Yau (2009), Hamza (2015) and leaf area/plant in both studied seasons was affected significantly by plant density where the results showed that the highest leaf area/plant at the lowest density (35000 plants/fad.).

These results could be attributed to the competitions to light inter caption. In crowded planting, some of the lower leaves die probably because they don't intercept enough radiation energy for maintenance.

These results are in conjunction with those reported by Keshtah (1981), , Sharshar (1982) and Hamza (2015). They showed that when plant density was increased the plant growth character decreased.

On the other hand, leaf area index (LAI) had another trend in both studied seasons.

LAI increased with increasing plant density, where the highest plant density (70000 plant/fed.) had the largest leaf/area index (LAI). The increase in LAI may be due to reduction the area of land occupied by the plants. These results are in concordance with findings of Sharshar (1982), Ashoub (1984), Mansour (1988) and Hamza (2015). They found that LAI of plants was increased by increasing the plant density.

\section{2- Effect of nitrogen soures :}

Generally, plant height increased with plant age till 107 days from sowing. This was true in both season and in all nitrogen forms used in this study. Nitrogen forms i.e. Ammonum sulphate, Ammonium nitrate and urea 
did not significantly affect on plant height at 65 and 86 days from sowing, but at 107 days from sowing showing that urea was the better form of nitrogen which had the highest plants than the other forms in both growing seasons.

Number of greens/plant in both seasons not significantly affected by using any form of nitrogen at the three stages, i.e. 65,86 and 107 days from sowing .Similar results were obtained concerning number of branches/plant which not affected by nitrogen sources at the three growth stages in both seasons.

Data showed in Table 2 indicate that dry weight/plant (gm) not affected by nitrogen sources under the three studied ages. Nitrogen forms did not show any significant effect on the trait of leaf area/plant in both seasons at the three growth stages except at 107 days from sowing in 2016/2017 growing season, only (Table 3). Leaf area index in both growing season and at the three studied growth stages did not significantly affected by using any of the three nitrogen forms used in this study.

\section{3- Effect of nitrogen rates :}

The effect of nitrogen levels on studied traits, i.e. plant height, number of green leaves/plant, dry weight/plant, number of branches/plant, leaf area and leaf area index at the three growth stages, i.e. 65, 86 and 107 days from sowing are represented in Tables (1,2 and 3).

Comparisons among ever ages of plant height as affected by nitrogen levels reflected one trend in both seasons. Any increase in nitrogen application resulted in an increase in plant height.

These results are in harmony with those obtained by Rahman et al. (1978), Sharshar (1982), Ashoub (1984) and Mansour (1988).

Comparison among average of number of green leaves/plant as affected by nitrogen levels reflected on the same trend in both studied seasons. Any increase in nitrogen application resulted in an increase in number of green leaves/plant. Contrary of that, Abdrabu (1981) demonstrated that number of leaves/plant were not affected by nitrogen rates.

The results also indicated that adding nitrogen fertilization significantly increased the number of branches/plant at all growth stages. Test results are in accordance with those reported by Kamel (1970), El-Kafoury (1978), Sharsher (1982), Mansour (1988) and Hamza (2015).

They illustrated that nitrogen fertilizers increased number of branches per plant. The differences in total dry weight/plant due to nitrogen fertilization were significant at the different growth stages. Any increase in nitrogen 
application consistently increased the dry weight/plant Nitrogen fertilization accelerate the vegetative growth, hence plants accumulated more dry matter in different organs. Similar results were obtained concerning leaf area/plant and leaf area index in both seasons at any growth stage this weight may be attributed to the increase in both leaf number and leaf size. Also, nitrogen fertilization are important in preventing premature death of leaves due to nutrients deficiencies. These results are in accordance with those obtained by Kamel et al. (1982), Sharshar (1982), Mansour (1988) and Hamza (2015). They stated that leaf area and leaf area index were increased by increasing the level of nitrogen at any age.

Conclusively, from these results it could be concluded that to increase the number of branches' / plant and leaf area index should be apply $60 \mathrm{~kg} / \mathrm{fed}$ level of nitrogen with low plant density,

\section{REFERENCE}

Abdrabau, R.T. (1981). Relationship between Leaf Area Index and yield quality of sunflower and safflower plants. Ph. D. Thesis, Faculty of Agric. Ain-Shams Univ., Egypt.

Abu-Hagaza NM, Mahrous N, Mohamed SA, Abd El-Hameed MH. 2009. Response of some promising safflower genotypes to nitrogen levels under drip irrigation in Wadi El-Natroon. Egyptian J. of Plant breeding, 13: $183-198$

Ahmed, Z., S. Meddekkar and S. Mohammad, 1985. Response of safflower to nitrogen and phosphorus. Indian Agron., 30: 128-130.

Amoughin RS, Tobeh A, Somarin S. J. 2012. Study on the effect of different plant density on some morphological traits and yield of safflower under irrigated and rain-fed planting conditions. International J. Agron. and Plant Production, 3(8): 284-290.

Ashoub, A.H. (1984). Effect of some cultural treatments on the yield and quality of safflower. Ph. D. Thesis, Faculty of Agric. Cairo Univ.,Egypt.

Cabı, R., 1990. Effects of form and levels of nitrogenous fertilizer on the safflower yield and other important traits Ondokuz Mayıs Üniv. Agric. Fac., Samsun.

Duncan, B. D. (1955). Multiple range and Multiple F. test. Biometrics, 11:142. 
Elfadl E, Reinbrecht C, Frick C, Claupein W. 2009. Optimizing of nitrogen rate and seed density for safflower (Carthamus tinctorius, L.) production under low-input farming conditions in temperate climate. Field Crops Res., 114: 2-13.

El-Kafoury, A.A.R. (1978). Effect of some cultural practices on yield and oil technological properties in safflower. M. Sc. Thesis, Fac. Of Agric. AlAzhar Univ., Cairo, Egypt.

Emami T, Naseri R, Falahi H, Kazemi E. 2011. Response of yield, yield component and oil content of safflower (cv. Sina) to planting date and plant spacing on row in rain fed conditions of western Iran. AmericanEurasian J. Agric. And Environ. Sci., 10(6): 947-953.

Hamza, M. (2015), Influence of different plant densities on crop yield of six safflower genotypes under Egyptian newly reclaimed soils conditions. International journal of agric. And Crop Sciences, 8(2) 168-173.

Jones, J.P. and T.C. Tucker (1968). Effect of nitrogen fertilizers on yield, nitrogen content and yield components of safflower. Argon. J., 60 (4): 363-364.

Kamel, M.S.; R. Shabana, E.A. Mahmoud and M.M. Keahtah (1982). Associations between growth attributes of safflower (Carthamus tinctorius L.) and yield of seed and oil under different production practices. Zeitschrift fur Ackerund phlan Zenbau., 151 (3): 169-175.

Kamel, M.A.M. (1970). Effect of different levels of NPK fertilizers on the physical and biochemical properties of safflower oil. M. Sc. Thesis, Fac. Of Agric. Ain-Shams, Univ, Egypt.

Keshtah, M. M. A. (1981). Growth, yield and quality of safflower as affected by row spacing, hills spacing and nitrogen fertilization level. M. Sc. Thesis, Faculty of Agric. Cairo Univ. Egypt.

Mansour, A.A.. (1988). Effect of plant density and fertilization on safflower. M. Sc. Thesis, Faculty of Agric. Zagazig Univ. Egypt.

Shahri A, Ganjali HR, Fanayi HR. 2013. Effect of drought on quantitative and qualitative yield of safflower (Goldasht cultivar) in different planting densities. International J. Agric. and Crop Sci., 6(19): 1342-1346.

Sharahar, M. S. A. (1982). Effect of plant spacing and nitrogen fertilization on safflower growth, yield and its components. M. Sc. Thesis, Faculty of Agric. Tanta Univ., Egypt. 
Sharifmoghaddasi MR, Omidi AH. 2009. Determination of optimum rowspacing and plant density in Goldasht safflower variety. Advances in Environ. Biology, 3(3): 233-238.

Tamer Eryiğit1, Bünyamin Yıldırım, A. M. Kumlay, and Sezgin Sancaktaroğlu (2015). The Effect of different row distances and nitrogen and nitrogen fertilizer rates on yield components of safflower (Carthamus tinctorious) under micro-climate conditions of Iğdır PlainTurkey 3rd International Conference on Biological, Chemical and environ. Sciences Sept. 21-22, 2015 Kuala Lumpur (Malaysia).

Weiss EA. 2000. Oilseed Crops, 2nd ed., Blackwell Science, Oxford, Chapter: 4, pp. 93-129.

Yau SK. 2009. Seed rate effect on rain fed and irrigated safflower yield in Eastern Mediterranean. The Open Agric. J., 3, 32-36.

\section{الصفات المورفسيولوجية للقرطم المتأثرة بالكثافة النباتية والتسميد الأزوتى لئى}

محمد إدريس عبد الحافظ ، على عبد الحميد حسان، عبد الغتى عبد المعطى منصور، أحمد أبو القتوح حمودة إلتي قسم الإنتاج النباتي ـ كلية التكنولوجيا و التتمية - جامعة الزقازيق ـ مصر

أقيم تجربنان حقليتان فى مزرعة خاصة بقرية المحامين مركز أرمنت محافظة

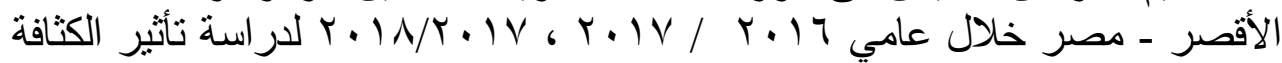
النباتية والتسميد الأزوتى ببمستويات وصور مختلفية على التى الصفات المورفولوجية

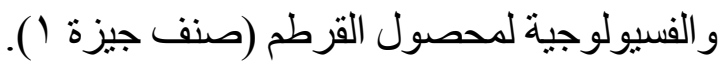

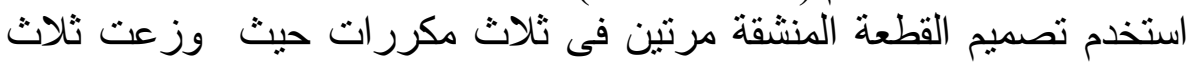

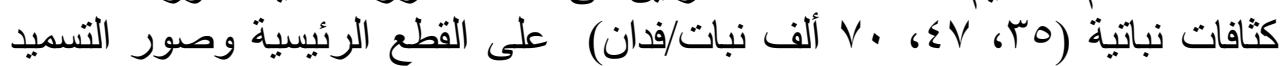

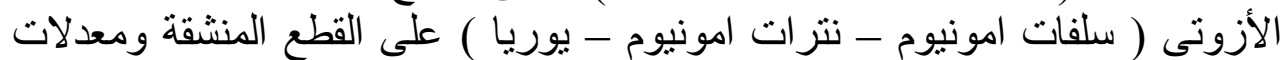

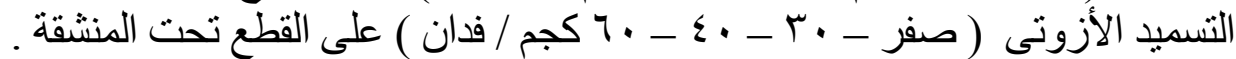

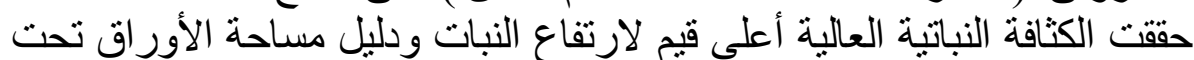

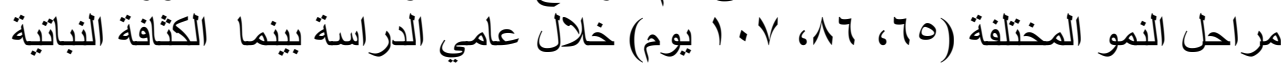

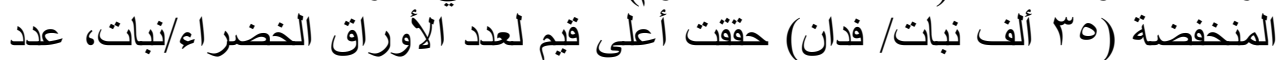


فروع النبات والوزن الجاف للنبات ومساحة أوراق النبات فى مراحل النمو المختلفة خلال موسمي الدر اسة.

معدلات التسميد الأزوتى أثرت معنوياً على جميع الصفات المدروسة خلال الصات

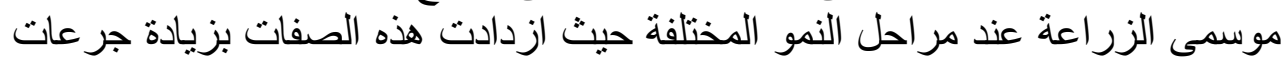

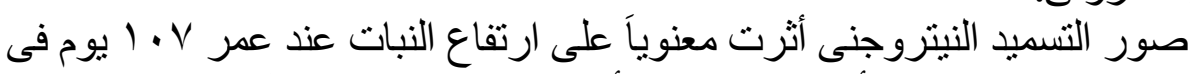

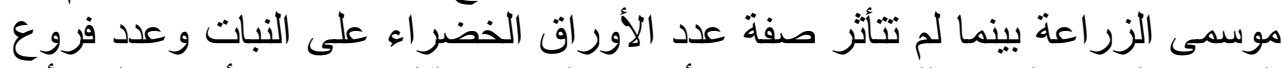

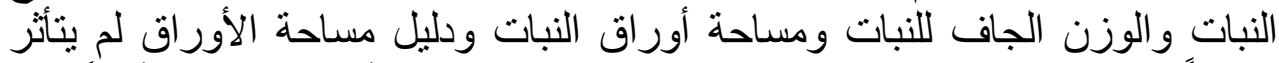

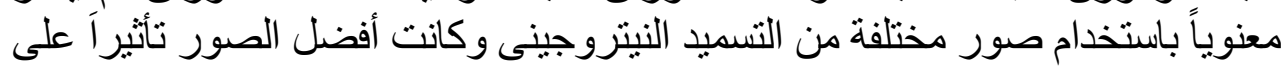

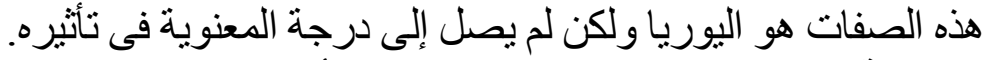

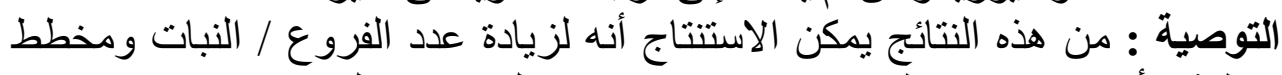

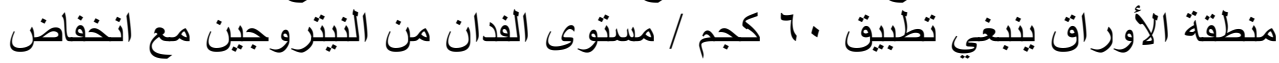
كثافة النبات. 